\title{
Identification and functional analysis of novel centrosomal proteins to study their implication in human disease
}

\author{
L Jakobsen ${ }^{1 *}$, JM Schrøder ${ }^{1}$, K Vanselow $^{1}$, EA Nigg ${ }^{2}$, E Lundberg $^{3}$, J Andersen ${ }^{1}$ \\ From First International Cilia in Development and Disease Scientific Conference (2012) \\ London, UK. 16-18 May 2012
}

The physiological importance of cilia is underscored by the ever-growing list of 'ciliopathies' associated with ciliary dysfunction. The many overlapping phenotypes of these syndromes might reflect the complexity of the ciliary proteome and the numerous functions of cilia. Likewise, dysfunction of a number of centrosomal proteins has been linked to human diseases. As centrosomes and cilia are closely linked, centrosomal abnormalities can also cause disease by affecting cilia formation, for example by affecting the docking of the basal body to the cell membrane, transport processes relying on microtubule interactions with the centrosome, targeting of membrane vesicles or the intraflagellar transport required for cilia assembly. It might thus be that a number of diseases could be more correctly referred to as 'centrosomeopathies'. Despite the identification of many centrosomal and ciliary proteins, it is still not known how many of these components interact and function. We have recently characterized the human centrosome proteome in depth using a quantitative mass spectrometry-based method in combination with an antibody-based screen, identifying several novel and candidate centrosomal proteins. The thereby obtained human centrosome proteome provides an excellent basis for further experiments to elucidate the multiple functions of the centrosome, including its role in human disease such as ciliopathies and cancer development. We are currently undertaking more functional experiments based on the improved centrosome proteome to investigate a possible role of these proteins in processes such as centriole duplication and ciliogenesis, both of which are processes with links to human disease.

* Correspondence: lisja@bmb.sdu.dk

'University of Southern Denmark, Denmark

Full list of author information is available at the end of the article

\section{Author details}

${ }^{1}$ University of Southern Denmark, Denmark. ${ }^{2}$ Biozentrum, University of Basal, Switzerland. ${ }^{3}$ School of Biotechnology, AlbaNova University Center, Royal Institute of Technology (KTH), Stockholm, Sweden.

Published: 16 November 2012

doi:10.1186/2046-2530-1-S1-P28

Cite this article as: Jakobsen et al:: Identification and functional analysis of novel centrosomal proteins to study their implication in human disease. Cilia 2012 1(Suppl 1):P28.
Submit your next manuscript to BioMed Central and take full advantage of:

- Convenient online submission

- Thorough peer review

- No space constraints or color figure charges

- Immediate publication on acceptance

- Inclusion in PubMed, CAS, Scopus and Google Scholar

- Research which is freely available for redistribution

Submit your manuscript at www.biomedcentral.com/submit
C Biomed Central
C Biomed Central

두 2012 Jakobsen et al; licensee BioMed Central Ltd. This is an Open Access article distributed under the terms of the Creative Commons Attribution License (http://creativecommons.org/licenses/by/2.0), which permits unrestricted use, distribution, and reproduction in any medium, provided the original work is properly cited. 